\title{
THE IMPACT OF SHARE CROPPING SYSTEM ON THE PRODUCTIVITY OF RICE FARMING IN CENTRAL JAVA
}

\author{
Lestari Rahayu Waluyati, Jamhari and Abi Pratiwa Siregar \\ Department of Agricultural Social Economic, Universitas Gadjah Mada, \\ Flora street No 1 Bulaksumur, Yogyakarta 55281, Indonesia
}

\begin{abstract}
The problem in rice production in Java is the decrease of agricultural land area, and the increase of old farmers, the share cropping system is a system of land tenure distribution that is mostly carried out in Java. The research was conducted in Klaten Regency as the centre for rice production in Cemtral Java. This study aims to determine the management of rice farming using a share cropping system and factors that affect its productivity. The research involved 60 farmers as the research samples who were collected using multiple linear regression methods. The analysis revealed that the number of tenant farmers amounted to $38 \%$ with a relatively younger age and a land area of 0.7 ha. Economically, they live a decent life with revenue per cost 1.6 and profit per cost $C 0.25$, and a productivity level of 6.3 tons/ha, which is higher than the landowners are. The share cropping system in rice farming in Klaten Regency is a system of land use and labor that provides good incentives for the tenant.
\end{abstract}

Keywords: Indonesia, Klaten Regency, productivity, rice farming, share cropping system.

Cite this Article: Lestari Rahayu Waluyati, Jamhari and Abi Pratiwa Siregar, The Impact of Share Cropping System on the Productivity of Rice Farming in Central Java, International Journal of Mechanical Engineering and Technology 11(4), 2020, pp. 0107.

http://iaeme.com/Home/issue/IJMET?Volume $=11 \&$ Issue $=4$

\section{INTRODUCTION}

The agricultural sector in Indonesia plays a strategic role in the national economic development. In fact, this sector is the main source of livelihood for around 38.29 million people $(34.00 \%)$, which constitutes the largest share of the entire Indonesian population listed in the workforce (BPS, February 2016). BPS data also stated that in 2016 the agriculture, forestry and fisheries sector contributed the second highest GDP with 13.34\% after the manufacturing sector $(21.02 \%)$. In addition, this sector is also the source of raw material supply as well as the market for the industrial sector. Certain agricultural commodities such as oil palm are the mainstay of foreign exchange for the country. However, it is notable that there are several problems at stake in the development the agricultural sector. These problems are attributed to various aspects, such as the growing shortage of agricultural area mainly in Java, the increasing number of old 
farmers, the lagging application of agricultural cultivation technology, postharvest handling, market information, and marketing and capital.

It is disconcerting that the rice field area is getting narrower from time to time, which may be attributed to greater land conversion for non-agriculture sector. Within the course of 10 years from 2002 to 2012, there has been a reduction of rice fields by 42,994 ha or by $4.3 \%$ (BPS, 2017). The study by Dwipradnyana (2014) [1] reveals that the driving factors of external conversion have a significant effect on land conversion. These driving factors affecting land conversion are the quality of land, the need for housing and the opportunity to buy land elsewhere. To reduce land conversion, it is advised that the government reinforce strict regulations in the licensing sector, especially by prohibiting building construction on wetlands. The government must also impose stern regulations on the sale and purchase of land, especially by stipulating the sale of agricultural land only for farming.

The growing shortage of agricultural land area of paddy fields leads to the increasingly decreasing agricultural land control. This alarming situation also corresponds to the growing number of older Indonesian farmers. In 2016, 61.8 percent farmers were over 45 years old, 26 percent were 35-44 years old, and only 12 percent were under 35 years old. Furthermore, the nominal daily wage of national farm laborers in November 2016 rose by 0.31 percent, higher than the wages of farm workers in October 2016, namely from Rp.48,368.00 to Rp.48,517.00 per day. However, real wages decreased by 0.55 percent. The December 2016 national NTP was IDR 101.49, which was 0.18 percent higher than the previous month's NTP. The increase in NTP was due to the Farmer Accepted Price Index (It) which rose by 0.53 percent, greater than the increase in the Farmer Paid Price Index (Ib) of 0.36 percent. In December 2016, Indonesia was hit by a rural inflation of 0.42 percent due to the increase of all household consumption index groups. The National 2016 Agricultural Household Exchange Rate (NTUP) in December 2016 was 110.72 , which rose by 0.35 percent and was higher than the NTUP of the previous month (BPS, 2017).

Some problems of the agricultural sector resulted from the growing shortage of agricultural land area, the increasing number of older farmers, and the higher wages of farm laborers make the landowners consider the share cropping system as one of the possible solutions. Old landowners will rent their land to the younger farmers who do not own any land. The share cropping system is deemed profitable because the younger tenant farmers do not have to pay for the rent. Working on a broad scale of rice field will earn a considerable income. Thus, this research aims to find out the management of the share cropping system carried out by the young generation of farmers and the factors affecting their productivity.

Although Marshall's theory [2] deemed the share cropping system as an inefficient system in land use and labor, some researches show that the share cropping system is more efficient than the labor wage system. This system increases land productivity so that both landowners and tenant will reap higher income. Cheung (1969) [3] states that the share cropping system is a system of land use and labor that consistently motivates the farmers to gain profits because of the risk sharing and low transaction costs. This view is in line with Reid's (1979) research who believed that the tenants get some incentives to work better. Waluyati's (1990) [5] research on rice farming in Sleman Regency shows that the system provides the tenant with the same productivity and efficiency as the landowner.

\section{RESEARCH METHOD}

The research was conducted in Klaten Regency as the rice production centre of The Central Java. Subdistrict samples were taken in Juwiring district, which serves as the main rice production center. Jaten village was selected since it owns a sample of farmer groups. The 
research used secondary data and primary data derived from the farmers by way of survey methods using structured interviews and questionnaires.

To calculate the cost structure and income of rice farming, and reveal information about the management of a share cropping system the study used table analysis. To find out the factors that influence rice productivity, the researcher used multiple regression analysis. Meanwhile, the feasibility of rice farming is known by business feasibility analysis, namely:

a. R/C Ratio $>1$

b. $\pi / C$ Ratio $>0$

$$
\mathrm{R} / \mathrm{C}=\frac{\text { Revenue }}{\text { Total Cost }}
$$

$$
\pi / \mathrm{C}=\frac{\text { Profit }}{\text { Total Cost }}
$$

c. $\frac{\pi}{C}$ Ratio $>\mathrm{r}, \mathrm{r}$ is the bank's interest rate (in this study, the KUR interest rate is 9 percent).

To determine the factors that influence rice productivity, the researcher used a multiple linear regression model with the Ordinary Least Square method. The mathematical equation of the factors that influence productivity is:

$\operatorname{Ln} Y=a+b_{1} \operatorname{Ln} X_{1 i t}+b_{2} \operatorname{Ln} X_{2 i t}+b_{3} \operatorname{Ln} X_{3 i t}+b_{4} \operatorname{Ln} X_{4 i t}+b_{5 i t} \operatorname{Ln} X_{5 i t}+b_{6} D_{1 i t}+b_{7} D_{2 i t}+b_{8} D_{3 i t}+u_{i t}$ Description:

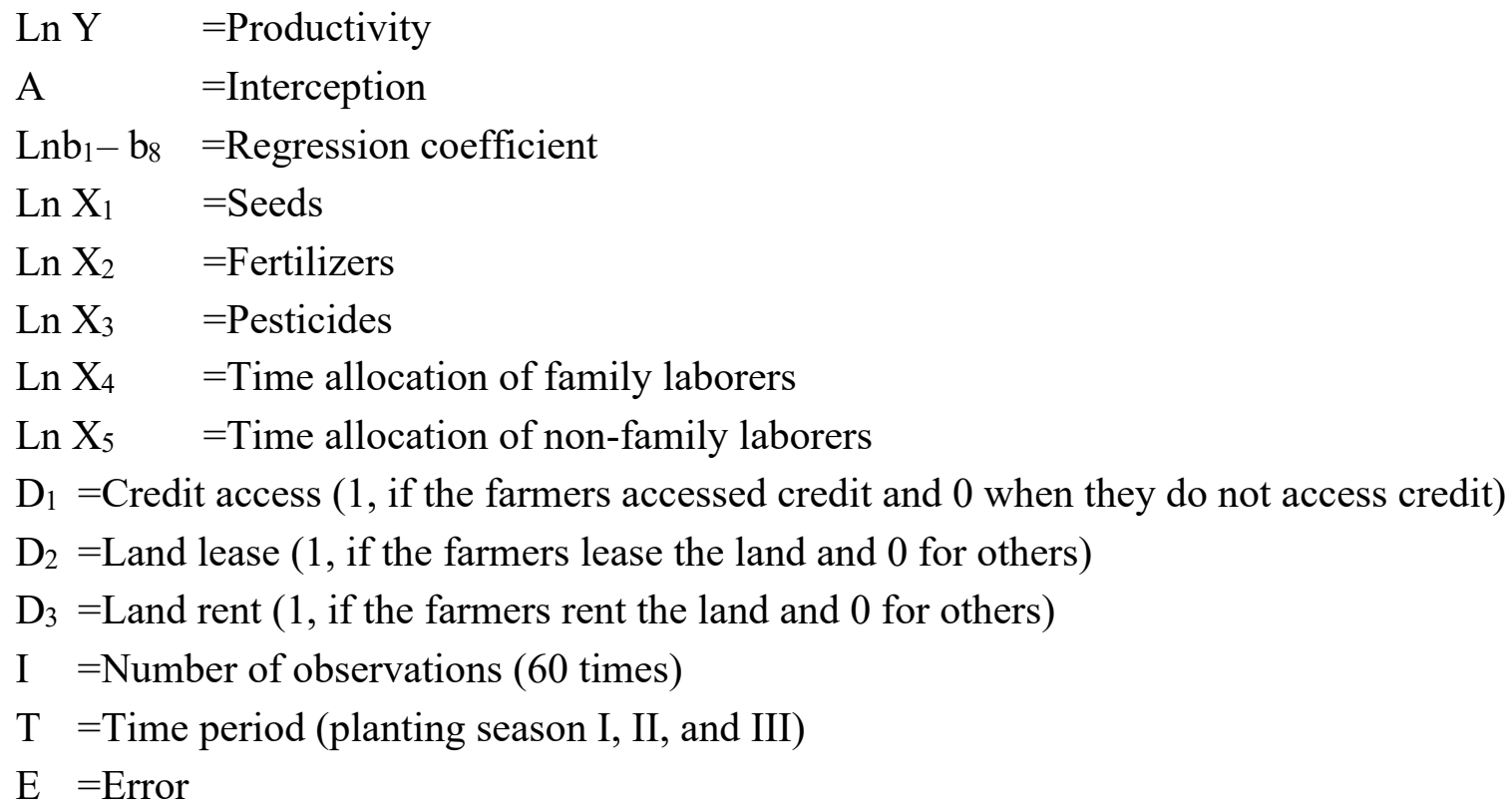

\section{RESULTS AND DISCUSSION}

The result showed that $38.33 \%$ of farmers are tenants and $36.67 \%$ are landowners (Table 1 ). With a considerable time, allocation for farming labor, 27.69 percent of farmers do not have side jobs.

The tenants are characterised by having the average age of 58 years, with the youngest age of 35 years. This is an interesting finding, which shows a farming transition from older to younger generation in food farming, especially rice. On the average, the farmers complete only the education level of junior high school (SMP), with the lowest level of education as not completing any level of study, while the highest level of education of undergraduate degree (S1). 
The average land area of the tenants is 0.7 ha. The feasibility of farming (R/C Ratio) of tenant farmers in each planting season is above 1 . The same $\mathrm{R} / \mathrm{C}$ ratio also applies for landowners. On average, during three planting seasons, the $\mathrm{R} / \mathrm{C}$ ratio of cultivators is 1.61 while the landowner is 3.01. Landowners' $\mathrm{R} / \mathrm{C}$ ratio are relatively higher than the cultivators because they do not have to spend on profit-sharing costs as a consequence of the share cropping system.

Table 1 R/C Ratio of Tenant Farmers and Landowners

\begin{tabular}{|c|c|c|}
\hline Planting Season & Tenant Farmers & Landowners \\
\hline I & 1,69 & 3,10 \\
\hline II & 1,81 & 3,40 \\
\hline III & 1,35 & 2,63 \\
\hline
\end{tabular}

The next indicator used to see the feasibility level of rice farming is $\pi / \mathrm{C}$ Ratio $>0$. This indicator is in contrast to the $\mathrm{R} / \mathrm{C}$ ratio, where the calculated cost is limited to explicit costs. In the calculation of $\pi / C$ the total costs are a combination of explicit and implicit costs. On the average of three planting seasons, the $\pi / \mathrm{C}$ ratio of the tenant farmers is 0.25 , while the landowners is 0.64 (Table 2). Both the landowners and tenant farmers earn a considerable income because the value is greater than zero.

Table $2 \pi /$ C Ratio of Tenant Farmers and Landowners

\begin{tabular}{|c|c|c|}
\hline Planting Season & Tenant Farmers & Landowners \\
\hline I & 0,34 & 0,74 \\
\hline II & 0,44 & 1,01 \\
\hline III & $-0,03$ & 0,22 \\
\hline
\end{tabular}

The productivity of tenant farmers and landowner is almost the same. During three planting seasons (Table 3), on the average, the tenant farmers can produce 6.3 tons for each hectare of cultivated land, while the landowners gain relatively lower with 6.1 tons per hectare.

Table 3 Ratio Productivity of Tenant Farmers and Landowner (tons/ hectare)

\begin{tabular}{|c|c|c|}
\hline Planting Season & Tenant Farmers & Landowners \\
\hline I & 6,5 & 6,2 \\
\hline II & 6,6 & 6,4 \\
\hline III & 5,7 & 5,7 \\
\hline
\end{tabular}

The factors affecting productivity are revealed using panel data multiple regression analysis. The dependent variable is productivity in planting season I, II, and III, while the independent variable is the per hectare amount of seeds, fertilizers, pesticides, time allocation for the family labors, time allocation non family labor, labor machinery, credit access, land use status (rent), and share cropping.

Its coefficient of determination is 0.44 . In other words, variations in the independent variables are able to explain production by 44 percent. The remaining 56 percent is explained by other variables outside the model.

Table 4 Results of Multiple Regression Analysis Factors that Influence Productivity

\begin{tabular}{|c|c|c|c|c|}
\hline & Coefficient & Std. Error & t- Statistic & Prob. \\
\hline C & $-1,673534$ & 0,129015 & $-12,97165$ & 0,0000 \\
\hline Seeds & $-0,040281^{* *}$ & 0,016170 & $-2,491177$ & 0,0137 \\
\hline Fertilizers & $0,078407^{* * *}$ & 0,021260 & 3,688012 & 0,0003 \\
\hline
\end{tabular}




\begin{tabular}{|c|c|c|c|c|}
\hline & Coefficient & Std. Error & t- Statistic & Prob. \\
\hline Pesticides & $0,052768 * * *$ & 0,013620 & 3,874318 & 0,0002 \\
\hline TKDK & $0,028567 * *$ & 0,011358 & 2,515218 & 0,0128 \\
\hline TKLK & $0,029732 * *$ & 0,014241 & 2,087733 & 0,0383 \\
\hline Credit Access & $0,329294 * * *$ & 0,109729 & 3,000980 & 0,0031 \\
\hline Use of Land Rent & $0,878902 * * *$ & 0,113087 & 7,771891 & 0,0000 \\
\hline Use of share cropping & $0,263252 * * *$ & 0,097613 & 2,696903 & 0,0077 \\
\hline R-squared & 0,466648 & & & \\
\hline Adjusted R-squared & 0,441696 & & & \\
\hline S.E. of regression & 0,556929 & & & \\
\hline F-statistic & 18,70173 & \multicolumn{2}{|c|}{ Durbin-Watson stat } & 0,2731 \\
\hline Prob(F-statistic) & 0,000000 & & & \\
\hline
\end{tabular}

Description:

$* * *$ : is significant at $\alpha=1 \%, * *$ : is significant at $\alpha=5 \%$

The $\mathrm{F}$ test reveals that all independent variables together have a significant effect on the dependent variable.

Table 4 shows that seeds, fertilizers, pesticides, time allocation of family laborers, time allocation of non-family laborers, machine labor, access to credit, land use status (rent), and land use status, have a significant influence on productivity. Seeds have a significant and negative influence on productivity. If other factors are considered permanent, every one percent increase in the use of seeds will result in a decrease in productivity of 0.04 percent. Generally, the farmers in Klaten Regency used Inpari, Ciherang, and Situbagendit rice seeds. The various seed types used in rice farming are based on preference. Therefore, in the planting season I, II, or III, the varieties used may not be the same. Nevertheless, some farmers in Klaten Regency pay attention to rain intensity in determining which seeds to use. When the rainfall intensity is estimated to be high, at the beginning of the planting season, these farmers tend to choose seed varieties with rather lower growth to avoid the risk of rice collapse easily, especially before the harvest season. The average use of seeds every planting season is $41.15 \mathrm{~kg}$. The first planting season normally requires more seeds than other planting seasons.

Fertilizers are revealed to have a significant and positive influence on productivity. The fertilizers' coefficient of 0.07 means that when other factors are considered constant, every one percent increase in fertilizer use will encourage an increasing productivity by an average of 0.07 percent. The use of excessive fertilizer will certainly increase the cost of rice farming production. In terms of plants and land, excessive fertilizer application can: (1) reduce soil fertility rates, and tend to cause soil acidity. Increasing acidity of the soil results in the inhibition of nutrient absorption, and (2) make the plants susceptible to pests and diseases because excessive Urea fertilization makes the plant succulent.

Likewise, the use of lower dose of fertilizer than the plants' need will lead to worse growth. Thus, it is necessary to provide the plants with balanced dose of fertilizers by administering balanced macro fertilizers that are in accordance with the needs of the plants and nutrient content of the soil, while taking into account the provision of other micro nutrients. The needs for fertilizers containing elements of N, P, K, and s can be taken from chemical fertilizers, while the micro nutrients can be taken from organic fertilizers or manure. 
Table 6 Dosage of Urea, KCL, and SP 36 Fertilizers based on Permentan Recommendation Number 40 / Permentan / OT.140 / 04/2007 (percent unit)

\begin{tabular}{|c|c|c|c|c|c|c|c|c|c|}
\hline \multirow{2}{*}{ Description } & \multicolumn{4}{|c|}{ Urea } & \multicolumn{3}{c|}{ KCL } & \multicolumn{3}{c|}{ SP 36 } \\
\cline { 2 - 11 } & $\begin{array}{c}\text { MT } \\
\text { I }\end{array}$ & $\begin{array}{c}\text { MT } \\
\text { II }\end{array}$ & $\begin{array}{c}\text { MT } \\
\text { III }\end{array}$ & $\begin{array}{c}\text { MT } \\
\text { I }\end{array}$ & $\begin{array}{c}\text { MT } \\
\text { II }\end{array}$ & $\begin{array}{c}\text { MT } \\
\text { III }\end{array}$ & $\begin{array}{c}\text { MT } \\
\text { I }\end{array}$ & $\begin{array}{c}\text { MT } \\
\text { II }\end{array}$ & $\begin{array}{c}\text { MT } \\
\text { III }\end{array}$ \\
\hline $\begin{array}{c}\text { Exactly according to the } \\
\text { recommendation }\end{array}$ & 35 & 35 & 37 & 0 & 0 & 2 & 0 & 0 & 0 \\
\hline Below than the recommendation & 30 & 33 & 35 & 100 & 97 & 83 & 62 & 68 & 70 \\
\hline Above the recommendation & 35 & 32 & 28 & 0 & 3 & 15 & 38 & 32 & 30 \\
\hline
\end{tabular}

Most farmers use KCL fertilizer and SP 36 with the amount below recommendations. Based on its usage, it is known that farmers rarely apply fertilizer based on predetermined recommendations because of their lack of budget to buy fertilizer. Most farmers prefer the application of Urea than other fertilizers such as KCL, and SP 36 in farming.

Pesticides have a significant and positive influence on productivity as shown by the coefficient of 0.05 , which means that if other factors are considered constant, every one percent increase in pesticide use will increase the average productivity by 0.05 percent. The research area is known as an area with a high rate of pest and disease attacks, mainly from planthopper. Thus, pesticides are certainly needed to combat the pests.

Labor in the family (TKDK) has a significant and positive influence on productivity as shown by the coefficient of 0.02 . In other words, considering that other factors are considered constant, every one percent increase in time allocation of family workers (TKDK) will increase the productivity by an average of 0.02 percent. The same also applies for the time allocated by non-family workers (TKLK), which has a significant and positive influence towards productivity. The coefficient of 0.02 means that if other factors are considered constant, every one percent increase in time allocation of TKLK will increase average productivity by 0.02 percent.

Similarly, credit access has a significant and positive influence on productivity. The coefficient of 0.32 means that if other factors are considered constant, the farmers who access credit will have higher average productivity by 0.32 percent than farmers who do not access credit for farming.

Status of land use (rent) has a significant and positive influence on productivity. The coefficient of 0.87 means that if other factors are considered constant, the farmers who rent land have higher average of productivity by 0.87 percent than farmers who do not rent land.

Status of Land use (swap) has a significant and positive influence on productivity. The coefficient of 0.26 means that if other factors are considered constant, the farmers who use land have higher average of productivity of 0.26 percent than farmers who do not work on land. This result is not in line with the research conducted in Bangladesh [6] highlighting that the productivity of the landowners is higher than that of the tenant farmers. However, the research of the current research conducted in Klaten Regency supported the theory of Cheung (1969) [3].

\section{CONCLUSIONS AND RECOMMENDATIONS}

1. Most tenant farmers are relatively young, with an average land tenure of 0.7 ha.

2. Rice farming with a share cropping system provides income and benefits for both landowners and tenant farmers.

3. Rice productivity of share cropping system is higher than the labor wage system, which is in line with Chung's theory. 


\section{Suggestion}

1. The share cropping system provides the farmers with considerable income and high productivity and it is a potential alternative to reduce land conversion rates.

2. The share cropping system encourages young people who do not own land to earn money from rice farming.

\section{REFERENCES}

[1] Dwipradnyana I Made. 2014. Faktor-faktor yang Mempengaruhi Konversi Lahan Pertanian serta Dampaknya terhadap Kesejahteraan Petani (Studi Kasus di Subak Jadi, Kecamatan Kediri, Tabanan).

[2] J. Martínez-Alier, Sharecropping: Some illustrations, The Journal of Peasant Studies, 10:23, 1983, 94-106, DOI: 10.1080/03066158308438199.

[3] Cheung Stephen N.S., The Theory of Share Tenancy (Chicago: University of Chicago Press, 1969).

[4] Reid, Joseph D., The Evaluation and Implications of Southern Tenancy, Agricultural History 53, no. 1 (1979): 153-69. www.jstor.org/stable/3742867.

[5] L.R. Waluyati, Pengaruh Status Penguasaan Lahan pada Usaha Tani Padi di Kabupaten Sleman., Universitas Gadjah Mada, Yogyakarta, 1990 (unpublished).

[6] Ahmed, M., \& Billah, M, Impact of sharecropping on rice productivity in some areas of Khulna district, Bangladesh Journal of Agricultural Research, 43(3), 2018, 417-430. https://doi.org/10.3329/bjar.v43i3.38390 